\title{
GAIT ANALYSIS IN THE 6-MINUTE WALK TEST IN PATIENTS WITH COPD
}

\author{
Jan Szczegielniak', 2, Sebastian Rutkowski', Anna Wdowiak', \\ Katarzyna Bogacz ${ }^{1,2}$, Jacek Luniewski ${ }^{1}$ \\ Opole University of Technology ${ }^{1}$ \\ MSWiA Hospital in Glucholazy ${ }^{2}$
}

\section{SUMMARY}

Professional literature provides various studies discussing gait pathologies depending on the type of nervous system and skeletomuscular system. There are, however, no complex studies discussing aspects of gait, such as walking pace, step length or step duration during the 6-minute walk test in patients with COPD. The objective of this work was, therefore, to analyse the gait of patients with COPD during the 6-minute walk test. It attempted to answer the question how gait parameters change during physical effort in case of patients with COPD.

The research included 33 in-patients with COPD (27 males and 6 females), with median age of $65.7 \pm 10.4$, treated in MSWiA Hospital in Glucholazy. For the purposes of gait analysis, the GaitRite mat was used to measure walking pace, step length and step duration. The mat was 4 meters in length and the active surface consisted of 14 thousand sensors. Pearson's correlation index and $t$ test were used to calculate the relationships between the tested parameters.

The analysis of the results showed that as the distance covered in the 6-minute walk test increased, the pace of walking decreased and the step duration and length significantly increased $(p<0.05)$. High correlations between the values of gait parameters and distance covered were observed.

The research showed statistically significant differences in the values of parameters indicating walk pace, step duration and step length between the first and the last tests.

Keywords: gait analysis, 6MWT, COPD.

\section{INTRODUCTION}

In case of patients with COPD, occurring dyspnoea reduces their capability of undertaking greater effort. As the disease progresses, dyspnoea increases limiting patients' effort tolerance. It reduces the mobility which did not cause any difficulties earlier. Professional literature provides a range of studies describing walking pathologies depending on the type of nervous system and skeleto-muscular system. There are, however, no complex studies discussing aspects of gait, such as walking pace, step length or step duration during the 6-minute walk test in patients with COPD.

The aim of this work was to analyse the gait of patients with COPD during physical effort. The research aimed to assess gait parameters, such as walk pace, step length and step duration, in the 6-minute walk test.

\section{MATERIAL AND METHODS}

The research included 33 in-patients with diagnosed COPD (27 males, 6 females) treated in the MSWiA Hospital in Glucholazy. Patients who qualified for adequate pulmonary rehabilitation model based on the results of effort tolerance test, spirometry and functional fitness test, were qualified for the research [1]. Pearson's correlation index was used to calculate the relationships between the tested parameters. Student's t-test was used to calculate statistical differences.

All patients were given a 6-minute walk test. The walk test is a simple and relatively reliable effort tolerance test and as such gives the possibility of using it as a useful tool for the evaluation of rehabilitation results and qualification for an adequate rehabilitation model [2]. The section of the corridor where the test was conducted was 30 meters in length. Starting at 5th meter, the 4-meter GaitRite mat was placed. Data was collected automatically in 6 trials per patient. The first measurement was made after 5 meters and the following ones - every 60 meters. The research required a stopwatch, Borg scale form and a manometer.

Before the test, blood pressure, pulse and dyspnoea level were recorded for each patient. The patients were clearly instructed on how to move appropriately during the test [3]. For 6 minutes the patients walked barefoot on a specified section of the distance at their highest possible pace. The patients were informed when they were supposed to walk along the mat which constituted an integral part of the corridor section. Every minute they were also informed about the time of the test. On completing the test, blood pressure, heart rate and dyspnoea level were recorded.

For purposes of gait analysis, the GaitRite mat was used to measure walking pace, step length and step duration. The mat was 4 meters in length and the active surface consisted of 14 thousand sensors. 


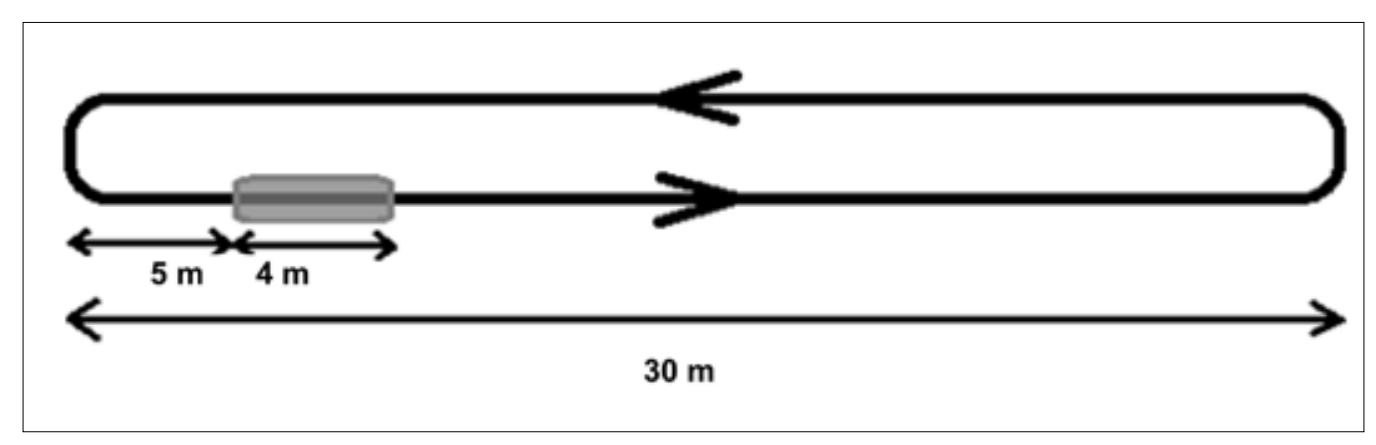

Figure 1. Patients' moving pattern during the 6-minute walk test

\section{RESULTS}

The results of the research were subjected to comparative analysis. Average values of particular gait parameters during the 6-minute walk test were calculated. Average distance parameter value achieved in the 6-minute walk test was $538.97 \mathrm{~m} \pm 176.32 \mathrm{~m}$. Gait parameters recorded in 6 measurements on the $305 \mathrm{~m}$ section (Table 1).

Table 1. Values of gait parameters in particular measurements

\begin{tabular}{|c|c|c|c|c|}
\hline \multicolumn{2}{|r|}{ Result } & $\begin{array}{c}\text { Pace, } \\
\mathrm{m} / \mathrm{s}\end{array}$ & $\begin{array}{c}\text { Step duration, } \\
\mathrm{s}\end{array}$ & $\begin{array}{c}\text { Step length, } \\
\mathrm{cm}\end{array}$ \\
\hline I & $5 \mathrm{~m}$ & $156.50 \pm 23.6$ & $0.478 \pm 0.03$ & $74.59 \pm 8.3$ \\
\hline II & $65 \mathrm{~m}$ & $154.52 \pm 25.4$ & $0.482 \pm 0.04$ & $74.89 \pm 9.5$ \\
\hline III & $125 \mathrm{~m}$ & $151.66 \pm 23.7$ & $0.485 \pm 0.04$ & $74.86 \pm 11.7$ \\
\hline IV & $185 \mathrm{~m}$ & $150.19 \pm 23.9$ & $0.487 \pm 0.04$ & $75.28 \pm 16.1$ \\
\hline V & $245 \mathrm{~m}$ & $147.06 \pm 23.4$ & $0.493 \pm 0.04$ & $75.68 \pm 20.7$ \\
\hline VI & $305 \mathrm{~m}$ & $146.45 \pm 24.6$ & $0.492 \pm 0.04$ & $76.11 \pm 25.6$ \\
\hline
\end{tabular}

Pearson's correlation index was calculated to assess the relationship between gait parameters and the distance covered in the 6-minute walk test.

High correlation between pace of walking, step duration and step length recorded in the effort tolerance test and the distance covered in the test was observed (Table 2).

Table 2. Pearson's correlation index values

\begin{tabular}{|c|c|c|c|}
\hline Gait parameter & Pace, m/s & $\begin{array}{c}\text { Step } \\
\text { duration, } \\
\text { s }\end{array}$ & $\begin{array}{c}\text { Step length, } \\
\mathrm{cm}\end{array}$ \\
\hline Distance covered & -0.99 & 0.98 & 0.97 \\
\hline
\end{tabular}

Correlation graphs were compiled to show the relationships between the length of the distance covered and the tested parameters. It was observed that the relationships were of linear character (Figure 4-6). As the distance increased, the pace of walking decreased, but step duration and length increased.

Statistically significant differences were observed between the values of step length, step duration and walk pace in the distance of 305 meters (Figures 2-7).

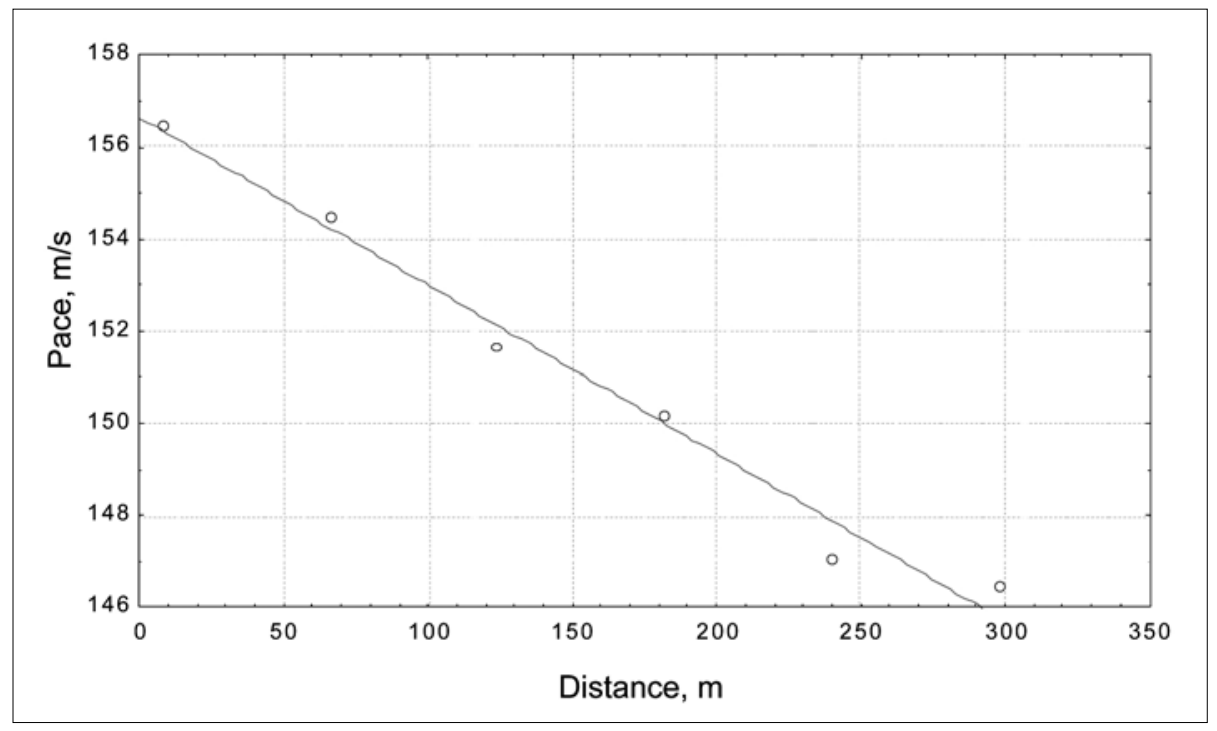

Figure 2. The relationship between the covered distance and walk pace 


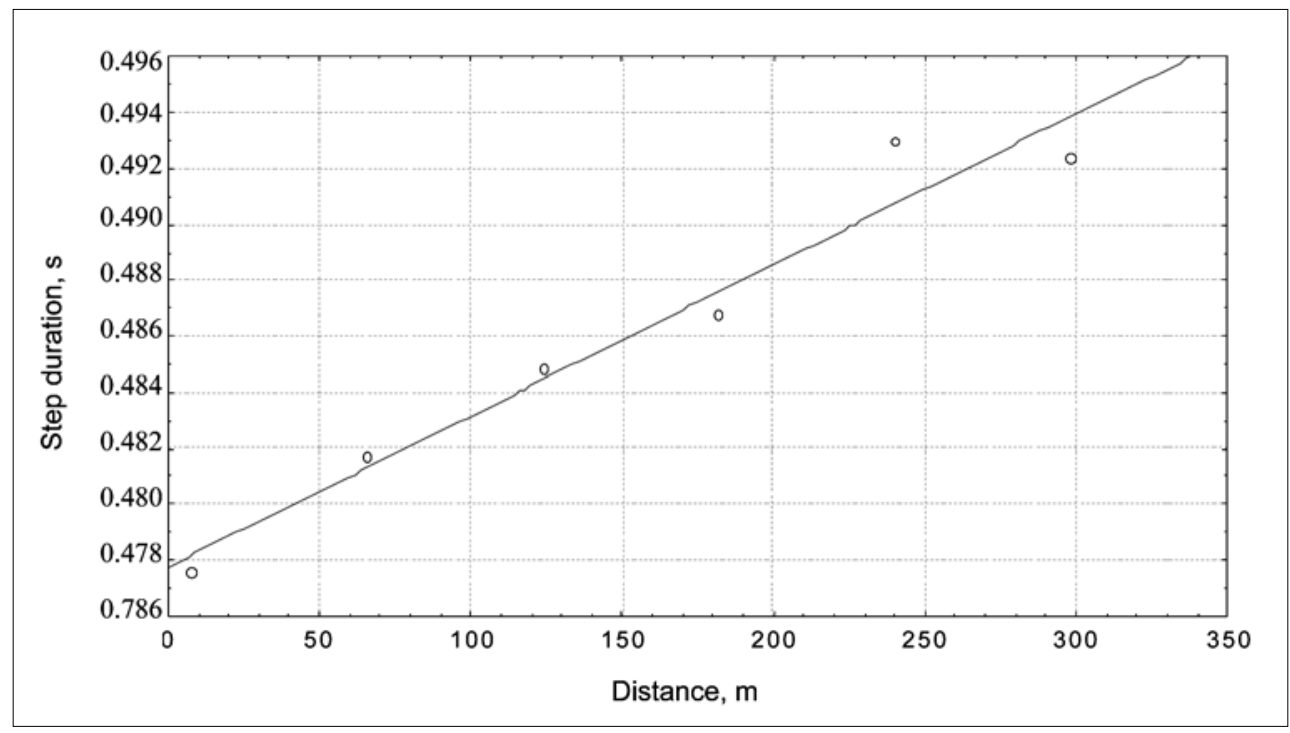

Figure 3. The relationship between the covered distance and step duration

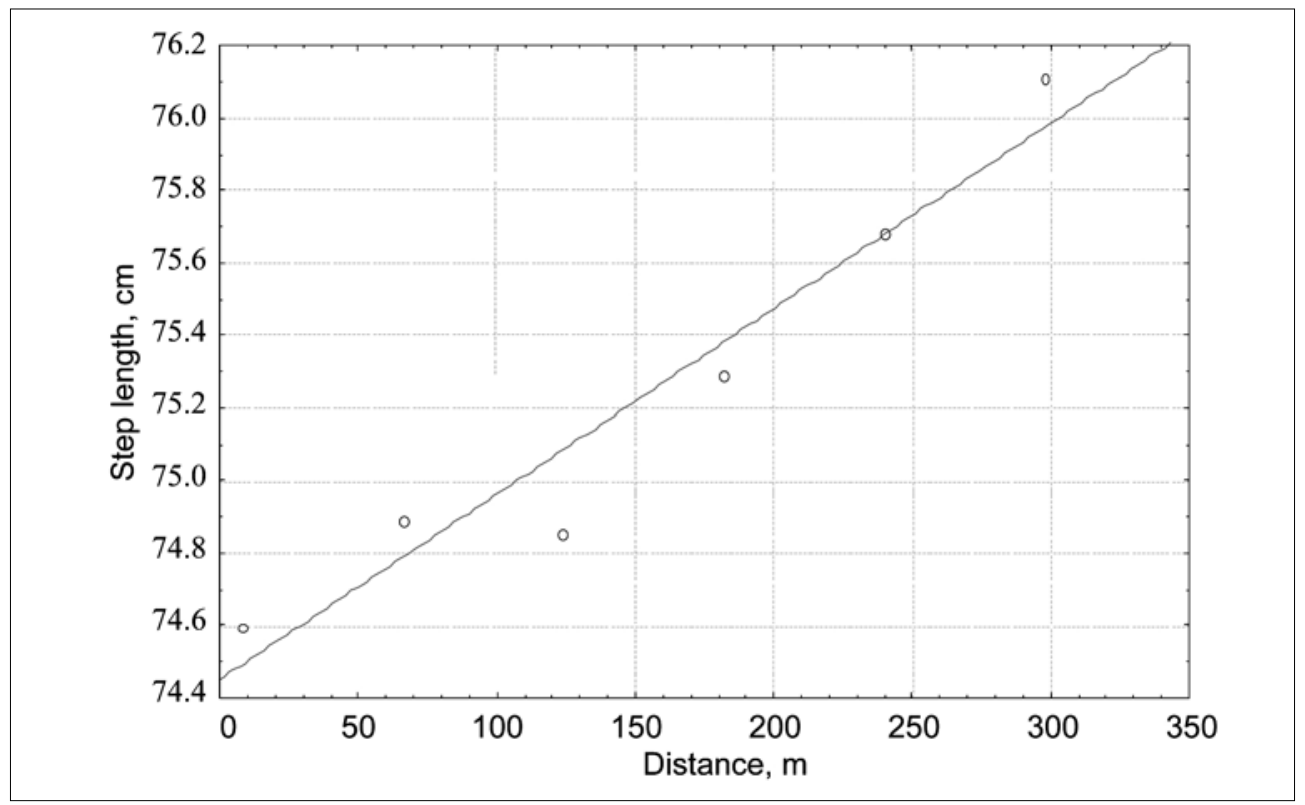

Figure 4. The relationship between the covered distance and step length

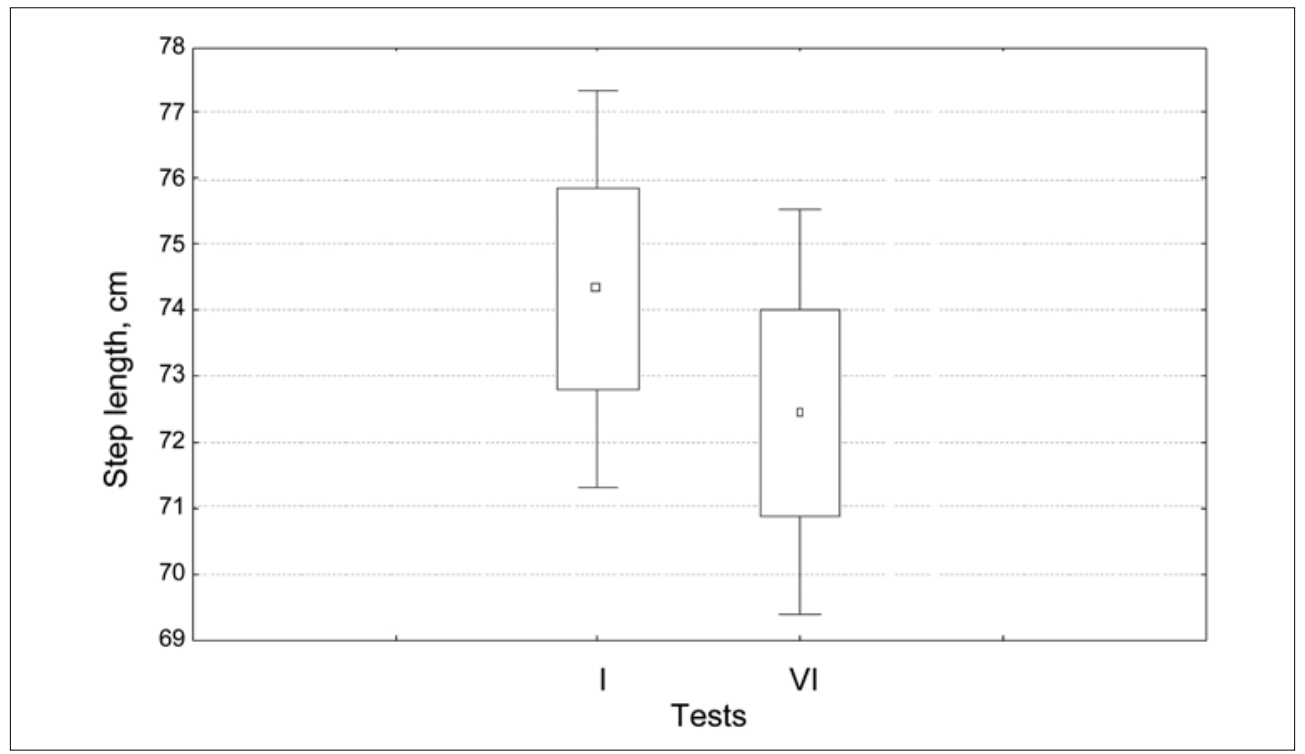

Figure 5. The difference between step length in measurements I and VI 


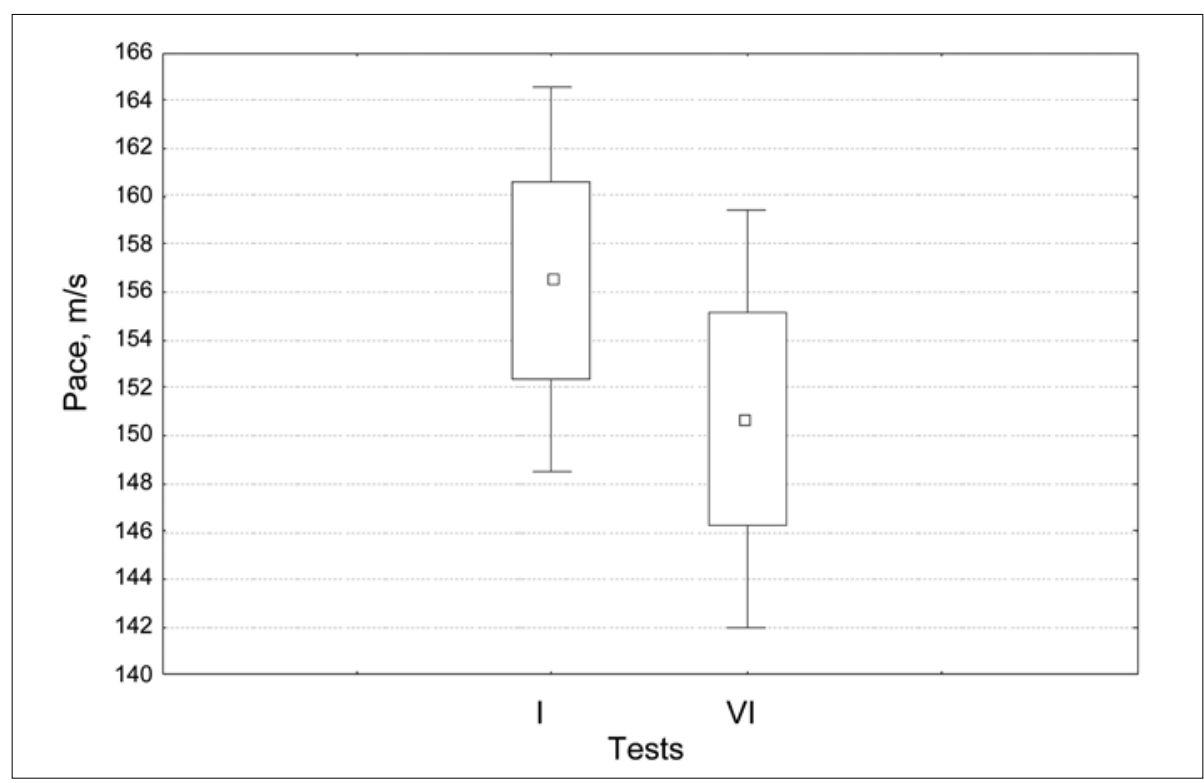

Figure 6 . The difference between walk pace in measurements I and VI

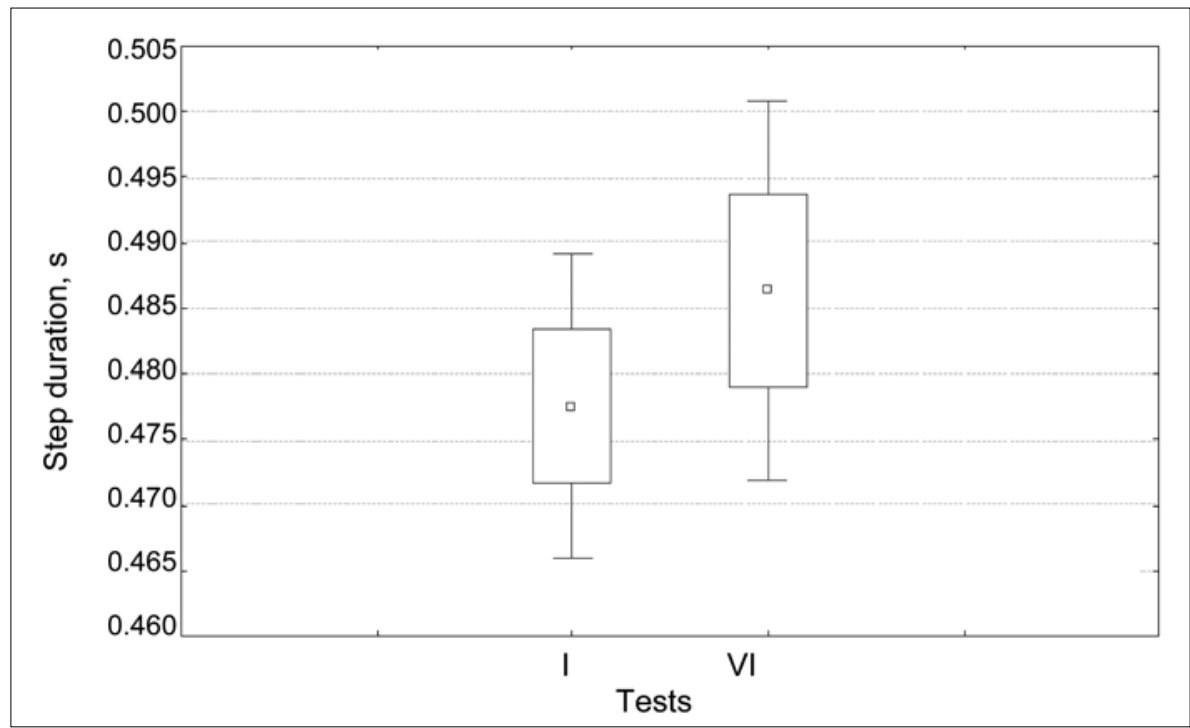

Figure 7. Difference between step duration in measurements I and VI

\section{DISCUSSION}

Apart from extensive inflammatory reaction, COPD also causes deterioration in patients' general functional state, a reduction in effort tolerance leading to skeletal muscle impairment [4], loss of muscle mass and bioenergetic disorders [5]. It is particularly true of lower limbs [6]. Research results related to lower limb dysfunctions in patients with COPD, e. g. quadriceps femoris muscle in the thigh have been reported by numerous authors $[7,8$, 9]. They prove that both strength and endurance of this muscle are significantly smaller in comparison with healthy individuals of the same age. It is worth noting that the strength of quadriceps femoris is highly correlated with effort tolerance in case of patients with COPD.

In their research, S. Butcher et al. [10] made an experimental attempt to assess coordination and its particular aspect being balance maintenance in standing position. Contrary to healthy individuals, patients with COPD frequently display difficulties in performing particular physical activities, including balance maintenance problems [10]. This aspect is of importance because balance maintenance ability allows for adequate performance of other, more complex motor activities, including walking.

N. A. Priest et al. [11] researched changes in walk pace of healthy Americans in two age groups $-80 \pm 9$ and $23 \pm 2$. The first test involved covering a specific distance at the pace which felt comfortable for the person tested. The second test involved covering the distance and performing specific tasks at the same time. In both age groups, smaller pace of walking was recorded during the two-task test [11].

It seems that due to the changes in effort tolerance tested walk parameters change in case of patients with COPD. 


\title{
CONCLUSIONS
}

1. High correlation between the values of tested parameters and covered distance was observed.

2. The research showed that walk pace, step duration and step length change significantly with the increase in the distance covered in the 6-minute walk test performed by patients with COPD. The longer the distance covered, the lower the walk pace but longer step duration and step length.

3. The research showed statistically significant differences in the values of parameters indicating walk pace, step duration and step length between the first and the last test.

\section{REFERENCES}

1. Szczegielniak, J., Bogacz, K., Luniewski, J. (2010). Kwalifikacja do rehabilitacji chorych na POChP. Praktyczna fizjoterapia $i$ rehabilitacja, 12, 9-11.

2. Szczegielniak, J., Bogacz, K., Luniewski, J. (2010). Program rehabilitacji chorych na POChP cz.l. Praktyczna fizjoterapia $i$ rehabilitacja, 12, 12-19.

3. American Thoracic Society. ATS Statement. (2002). Guidelines for the Six-Minute Walk Test. American Journal of Respiratory and Critical Care Medicine, 166, 111-117.

4. Howard, J., Green, M.,- Burnett, E. et al. (2005). Muscle fiber type characteristics in females with chronic obstructive pulmonary disease. Journal of Molecular Histology, 40, 41-51

5. Kołaczkowska, M. (2003). Światowa strategia rozpoznawania, leczenia i prewencji przewlekłej obturacyjnej choroby płuc. Terapia, 5, 20-26.

6. Wouters, E. F., Creutzberg, E. C., Schols, A. M. (2002). Systemic effects in COPD. Chest, 5, 127-130.
7. Degens, H., Sanchez, J. M., Heijdra, Y. F., Dekhuijzen, P. N. R., Hopman, M. T. E. (2005). Skeletal muscle contractility is preserved in COPD patients with normal fat-free mas. Acta Physiologica Scandinavica, 184, 235-242.

8. Van't Hul, A., Harlaar, J., Gosselink, R. et al. (2004). Quadriceps muscle endurance in patients with chronic obstructive pulmonary disease. Muscle Nerve, 29, 267-274.

9. Franssen, F., Broekhuizen, M. E., Janssen, R. et al. (2005). Limb muscle dysfunction in COPD: Effects of muscle wasting and exercise training. Medicine \& Science in Sport \& Exercise, 37 (1), 2-9.

10. Butcher, S., Meshke, J., Sheppard, S. (2004). Reductions in functional balance, coordination, and mobility measures among patients with stable chronic obstructive pulmonary disease. Journal of Cardiopulmonary Rehabilitation, 24 (4), 274-280

11. Priest, W. A., Salamon, B. K., Hollman, H. J. (2008). Age-related differences in dual task walking: A cross sectional study. Journal of NeuroEngineering and Rehabilitation, 5, 29.

\section{LIGONIŲ, SERGANČIŲ LĖTINE OBSTRUKCINE PLAUČIŲ LIGA, EISENOS ANALIZE் ATLIEKANT 6 MINUČIŲ ĖJIMO TESTA}

\author{
Jan Szczegielniak', 2, Sebastian Rutkowski', Anna Wdowiak', \\ Katarzyna Bogacz', ${ }^{1,}$ Jacek Luniewski ${ }^{1}$ \\ Opolés technologijos universitetas ${ }^{1}$ \\ Glucholazy MSWiA ligoniné ${ }^{2}$
}

\section{SANTRAUKA}

Profesinè literatūra aprašo įvairius tyrimus, kurių metu analizuojamos eisenos patologijų priežastys, susijusios su nervų ir griaučiųraumenų sistemomis. Visgi nèra kompleksinių studijų, aptariančių sergančiųjų lètinėmis obstrukcinėmis plaučių ligomis (LOPL) atskirus eisenos rodiklius (pvz., ejjimo tempą, žingsnio ilgi ar žingsnio trukmę) atliekant 6 minučių ejjimo testą. Tyrimo tikslas buvo išanalizuoti ligonių, sergančių LOPL, eiseną atliekant 6 minučių èjimo testą ir atsakant i klausimą, kaip keičiasi eisenos rodikliai fizinio krūvio metu.

Buvo tiriami 33 ligoniai, sergantys lètine obstrukcine plaučių liga (27 vyrai ir 6 moterys; vidutinis amžius - 65,7 $\pm 10,4 \mathrm{~m}$.) ir gydomi Glucholazų MSWiA ligoninèje. Analizuojant eisenos rodiklius (èjimo tempą, žingsnio ilgį, žingsnio trukmę) buvo naudojamas GaitRite kilimèlis. Kilimèlio ilgis - $4 \mathrm{~m}$, aktyvus paviršius susidèjo iš 14 tūkst. jutiklių. Pirsono koreliacijos kofecientas ir $t$ testas buvo naudojamai priklausomybei tarp vertintų rodiklių skaičiuoti.

Rezultatų analizè parodè, kad didèjant nueitam atstumui testavimo metu èjimo tempas mažèjo, žingsnio trukmė ir ilgis reikšmingai padidèjo $(p<0,05)$. Stipri koreliacija nustatyta tarp eisenos rodiklių ir nueito atstumo.

Nustatytas statistiškai reikšmingas skirtumas tarp eisenos rodiklių (ejjimo tempo, žingsnio ilgio ir žingsnio trukmės) pirmo ir paskutinio testavimo metu.

Raktažodžiai: eisenos analizè, 6 minučių èjimo testas, LOPL. 